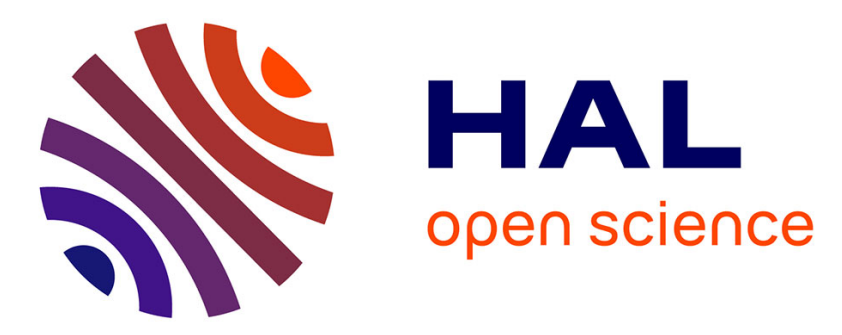

\title{
Polish Higher Education and the Global Academic Competition: University Rankings in the Reform Debates
}

Dorota Dakowska

\section{- To cite this version:}

Dorota Dakowska. Polish Higher Education and the Global Academic Competition: University Rankings in the Reform Debates. Tero Erkkilä. Global University Rankings: Challenges for European Higher Education, Palgrave Macmillan, pp.107-123, 2013, Global University Rankings: Challenges for European Higher Education, 9781137296863. hal-01184151

\section{HAL Id: hal-01184151 \\ https://hal.science/hal-01184151}

Submitted on 13 Aug 2015

HAL is a multi-disciplinary open access archive for the deposit and dissemination of scientific research documents, whether they are published or not. The documents may come from teaching and research institutions in France or abroad, or from public or private research centers.
L'archive ouverte pluridisciplinaire HAL, est destinée au dépôt et à la diffusion de documents scientifiques de niveau recherche, publiés ou non, émanant des établissements d'enseignement et de recherche français ou étrangers, des laboratoires publics ou privés. 
'Polish Higher Education and the Global Academic Competition: University Rankings in the Reform Debates', in : Tero Erkkilä (dir.), Global University Rankings: Challenges for European Higher Education. Palgrave Macmillan, 2013, p. 107-123.

\section{Polish Higher Education and the Global Academic Competition: University Rankings in the Reform Debates}

Dorota Dakowska

The use of statistics and indicators to evaluate public policies and higher education management in particular is not a new development per se. Communist countries of Central and Eastern Europe relied heavily on these instruments and planification was used in all sectors (Rowell, 2006; Pirker et al., 1995). However, it would be difficult to compare the scientific management of higher education by the communist states with the policies of their successors who seek to harmonise their higher education systems with their European counterparts in order to keep the pace of global academic competition. In most countries of the Soviet Bloc, higher education institutions (HEIs) were treated as administrative units. The planification was based mainly on input-oriented material indicators (such as the numbers and social origin of students) rather than on output-oriented, non-material aspects. From a contemporary perspective of higher education management, not only do the indicators used differ, but their purpose has changed. Since the fall of the communist regimes, the idea of academic competition driven by market forces and international mobility of workers has been constructed as a new imperative. This paper seeks to analyse how the Polish higher education 
community has reacted to this constraint, how it has tried to accommodate it and how the injunction of competition has been used by experts and policy-makers. ${ }^{1}$

The diagnosis of Poland's weak position in the global academic competition and the proclaimed need to improve its ranking in international university league tables have played a significant role in the domestic debates on higher education reform of the last decades. Poland provides an interesting case study to test the hypotheses advanced in this book. First, the recurrent reference to the idea of competitiveness testifies to the pervasiveness of the 'imaginary of competition', which has been enhanced by the proliferation of international rankings (Erkkilä, in this volume). Secondly, the Polish case confirms that global rankings have policy relevance insofar as they are used by experts and decision-makers as legitimising references. Thirdly, they allow domestic experts not just to reflect on their country's position in the European context (measuring the gap with the most successful West European universities or comparing their achievements with other countries in the region), but beyond that, to refer to the model of the top HEIs, located mainly in the United States (US).

However, it is not sufficient to state that rankings matter without asking how they matter and to whom. Tero Erkkila and Ossi Piironen (in this volume) remind us that determining the mechanisms through which rankings impact higher education policies at macro or micro level remains an analytical challenge. This contribution intends to give some answers to these questions, primarily by bringing some contextual elements into the demonstration. It cannot be claimed that rankings exercise power per se, independently of temporal, political and social conditions. Furthermore, the analytical approach of global rankings has to be specified. These policy instruments, based on specific indicators, with different weightings attributed to each of them, have been largely analysed through the lens of their methodology (Usher and Medow, 2009; Shin et al., 2011). A number of authors have focused on their development, their diffusion and their political significance (Marginson and 
van der Wende, 2007; Kehm and Stensaker, 2009; Kauppi and Erkkilä, 2011; Hazelkorn, 2011; Tofallis, 2012). However, their policy impact, which has been reflected in these recent stimulating works, needs to be further investigated.

The present contribution argues that while focusing empirically on a domestic policy field, it would be analytically risky to consider global rankings as the main incentive for reform. The legislative acts do not necessarily refer to university rankings. However, the public justification of the higher education reforms stresses the necessity to improve the quality and competitiveness of domestic higher education and research. Top decision-makers explicitly state that their objective is to give Polish universities a decisive push to improve their position in leading international rankings. Tracing a causal relationship between these rankings and the final legislative outcome entails some methodological challenges. It is difficult, first, to demonstrate the rankings' impact precisely and, secondly, to disentangle them from other reform triggers.

This contribution will favour a sociological-constructivist perspective (Rowell and Mangenot, 2011) focusing on the social and political uses of rankings. I analyse how experts and decision-makers refer to international league tables in order to construct the (lack of) competitiveness of national higher education and research as a public problem. I agree that rankings can be considered as an element of 'global scripts' paving the way for reforms of university governance and funding (Gornitzka and Maassen, 2011 in this volume) or as part of international power struggles relating to higher education internationalisation, privatisation and student mobility (Kauppi and Erkkilä, 2011). According to Erkkilä (in this volume), the impact of rankings can be pinpointed through the way ideas of 'competition, economism and elitism' are being spread, leading to a global isomorphic trend. While this 'drive for uniformity in policies and practices of higher education' (Erkkilä, in this volume) has been noticeable in the Polish case, the issue of convergence could be further analysed. On the one 
hand, global and European scripts lead to converging agendas, which stipulate broad directions of university reform (Olsen and Maassen, 2010). On the other hand, when it comes to more detailed 'reform instrumentation', divergence may very well be the main outcome, as Åse Gornitzka and Peter Maassen (2011) have shown on the example of the Nordic model. Central and Eastern European Countries (CEECs) provide an illustration of the limits of convergence at the implementation level (Tomusk, 2007) even though they share several common features (Dobbins and Knill, 2009; Dobbins, 2011). Thus, it is useful to make a distinction between the general trends, which may be common to several new European Union (EU) Member States (NMSs), and country-specific policy implementation and justification, which relates to domestic actor configurations and power structures.

The first part of this contribution tackles the transformations of Polish higher education after 1989 in a more general European and international context. I argue that external incentives for reform may find a fertile ground in a country oriented on a path of reform, looking for policy models and inspirations and whose ruling elites have mostly declared themselves in favour of the neo-liberal ideology. The second part highlights the main arguments pertaining to the rankings in the public debates on higher education reform, focusing on the stakeholders, mainly experts and policy-makers, who were most active in introducing this issue. This gives some insight on the way in which rankings, or, to be more precise, the position of Polish higher education and research in the global competition have been used to justify and shape the recent reforms. Furthermore, I show that the issue of a (lacking) competitiveness of Polish academic system has been constructed in expert discourse as a major public problem. The third part tackles the question asked by Barbara M. Kehm in this volume: who benefits from the rankings? In other words, I ask who stands to gain from the narrative of the necessity of a radical higher education reform, in which the rankings' verdict reaches the status of a universal truth. To conclude, an estimation of the rankings' 
impact will be proposed, knowing that it is only possible to speak of an indirect impact at best.

\section{The Transformations of the Polish He System: Between Liberalisation and}

\section{INTERNATIONALISATION}

The perceived necessity of catching up with Western universities and standards has been the main impetus of Polish higher education reforms since 1989. This argument was further legitimised by the liberal ideology that came to prevail after the post-communist transition and by the conditionality of the EU accession process that began in the mid 1990s and became effective in 2004. This pre-accession period coincided with the launching of the Bologna Process in 1999. As such, international rankings did not play any major role until the mid 2000s, when the Shanghai Academic Ranking of World Universities (ARWU) started having a global impact. However, the context of systemic transformations combined with the preparations for the EU accession provided a fertile ground for a reflection on the quality of teaching and research and for international comparisons. From the beginning of the 1990s, Polish higher education became increasingly internationalised, which implied transnational policy transfers, as well as the adoption of specific quality assessment instruments and the related technical lingo.

In the early 1990s, CEECs' higher education systems underwent a relative internationalisation due to exposure to institutions active in the field of education such as the Organization for Economic Cooperation and Development (OECD), United Nations Educational, Scientific and Cultural Organization (UNESCO) or the Council of Europe but also of the World Bank and of private organisations such as the Soros Foundation. The first higher education and research reforms adopted after 1989 were based on international inspirations, which did not necessarily come from Europe but rather from the United States. 
For instance, the State Committee for Scientific Research (KBN), created in 1991, which institutionalised the principle of competition between researchers applying for grants, was inspired by the American National Science Foundation (Jabłecka, 2009). ${ }^{2}$

In the very first years after the fall of the communist regime, the new ruling elites tried to establish new principles in higher education and research policies, such as open competition in applying for grants and scholarships, while opening up the domestic academic system to Western standards. This was a period of exposure to and inspiration by international academic procedures such as quality assessment, accreditation, peer review, and so on. Meanwhile, the participation of Polish experts in international projects such as OECD student performance assessments opened the discussion on the quality of the domestic educational system.

Among other CEECs, Poland may be considered as a forerunner of the reform process. The legal conditions for higher education transformation were set up early and their outcome proved in many respects spectacular. The legal basis for tertiary education reform was provided by the Higher Education Act of 12 September 1990. This text was written by both lawyers and academics linked with the new democratic government. These academics had as a rule gained international experience and used their knowledge of foreign higher education systems to shape the new legislation. Their priorities were to re-establish academic freedom and collegiality, as a reference to the interwar period. While the main aim of this new legal framework was to grant a large autonomy to HEIs, its most visible outcome was to pave the way for a far-reaching marketization of the sector. ${ }^{3}$ The mushrooming of private HEIs, who nowadays enrol a third of all students, was a somewhat unexpected result of these first legal regulations (Dakowska, forthcoming). The massification of higher education became a subject of debate, considered either as the greatest success of the initial reforms or as a threat for the quality of tertiary education. The Act on Higher Vocational Schools, adopted in 1997, has 
further contributed to the development of the non-public sector, especially of HEIs offering exclusively BA-level courses.

The international and especially European references became more visible in the context of EU accession. While some HEIs implemented measures aiming to facilitate students' mobility (such as the European Credit Transfer System or the two-tier degree structure) on a bottom-up and voluntary basis as early as in the 1990s, the perspective of accession provided an opportunity for more directive interpretations of the formally nonbinding Bologna principles (Dakowska, 2011). The 2005 Higher Education Act translated the proposals of the Bologna ministerial meetings into a legal framework. However, this reform was deemed insufficient by the new liberal majority led by the Civic Platform that came to power in 2007. The new Higher Education Minister, Barbara Kudrycka, was eager to launch more comprehensive reforms of the academic system. The debates on the best way to modernise higher education so that it could keep up with the pace of global and European competition gained new clout due to the public reception of global rankings. In this context, the government has adopted a series of legal acts reforming the research system in 2010 followed by a Higher Education Act, which has entered into force in October 2011. ${ }^{4}$ These reforms are an answer to international developments such as the Bologna Process but they also reflect more indirectly the rise of global university rankings.

\section{Rankings And EduCational Competition in the Reform Debates}

The debates on higher education governance and preferred models have involved experts, stakeholders as well as political and administrative decision-makers. These debates gained new clout in the public space during the preparation of the successive pieces of legislation relative to higher education. These legal acts are based, as will be shown further in this article, on the diagnosis of an insufficient competitiveness and visibility of Polish HEIs. 
Here is why these reforms come about, in general: the low quality of research, low quality of teaching, weak competitiveness of Polish science abroad, which explains our low position in international rankings - these are the principal factors (Civil servant, 2010).

This diagnosis has been formulated in several ways in strategic documents and public debates by the supporters of the reform project. The debate involving the academic community proved controversial. Beyond a wide consensus on the globally fragile position of the domestic research and higher education, many voices insisted that the problem was linked to a structural deficit of public funding. A defensive position consisted in arguing that some disciplines were doing relatively well in international comparisons or that some requirements promoted by the reform's supporters, such as academic mobility, could hardly be implemented in the Polish context due to local conditions such as the housing problems.

Even if international rankings have only had an indirect impact on higher education reforms, it is still worth analysing who has referred to these rankings and in what context. On the one hand, we should ask whether experts or representatives of the academic community, who publicly stress the importance of rankings, can gain an extra audience among the policymakers who are particularly sensitive to this issue. In other words, can the public reference to rankings be considered as a resource which may, under certain conditions, provide gains in terms of visibility or career? On the other hand, beyond these few 'ranking entrepreneurs', many experts (civil servants and academic representatives) who have participated in European and international working groups share a more distanced view of international university rankings.

During the recent debates on Polish higher education reform, the Shanghai and Times Higher Education Supplement (THES) rankings were used by pro-reformist representatives of the academic community to support their claims concerning the dire state of Polish higher 
edication and research. The existence of a growing competition on the 'global market of educational services' was used as an argument to call for a much stronger differentiation between the domestic HEIs, out of which only a few excellent establishments should concentrate the lion's share of public funds: 'Only a healthy competition in the fight for financial resources will force the HEIs, at least those who have scientific ambitions, to hire the best people, to be able to apply for grants and get rid of lazy people and losers.' (Jajszczyk, 2008)

The reformists referring to the global rankings do it in a largely standardised way, which allows them to pinpoint several problems simultaneously. First, they regret that Polish universities are weak in the main rankings (ARWU and THES), as only two or three of them appear among the first 500 and usually at a low level (fourth tier). They argue that in most countries the stakeholders monitor these rankings closely, and by contrast criticise what they see as a domestic neglect of this tool.

I know only one country where hardly anybody thinks seriously about the rankings, unless it is to question their weight or their methodology. This is Poland of course, where according to most professors as well as students, higher education is obviously excellent whereas global rankings are just an Anglo-Saxon manipulation. (Jajszczyk, 2009)

As a rule, the position of Polish HEIs is then compared to those of other countries named in the rankings either to show that many European and Asian countries fare better or to suggest that it is hard to compete with rich and well-known leading US universities. The reference to other CEECs can also be used by reformists to stress that the Charles University is doing better than leading Polish universities and that a voluntary policy of higher education internationalisation such as it is pursued by Prague may lead to tangible effects. Focusing on 
the 'champions' league' of global rankings clearly benefits the American higher education system as the US universities fare the best.

We should make more use of the experience of European Union countries, in which higher education reforms have been undertaken during the last years. We should also look for solutions stemming from the USA, as one of the objectives of European higher education and research policy is to ensure the competitiveness of European HEIs with their American counterparts. (Jackowski, 2004)

Among European establishments, Oxford and Cambridge are cited as examples to follow even though their specific history, financing and functioning make it difficult to transpose this model into Central and Eastern European countries. Furthermore, mentioning HEIs allows for making a direct link with international economic classifications such as the European innovation ranking or the rankings of the World Economic Forum, in which Poland and its research centres occupy low positions (Thieme, 2009b). This leads to converging appeals for a diversification of domestic HEIs. A recurrent argument heard in many European countries consists in saying that financial efforts should focus on a few select establishments which should thus become able to compete internationally. In this respect, Poland joins the club of countries from both the centre and periphery of academic production, where the ambition to reach top positions in the rankings has been explicitly stated. This framing reinforces the paradox of global rankings: the more decision-makers and stakeholders engage in the discussion about rankings, the more they contribute to legitimising this instrument (Hazelkorn 2011). At the same time, their HEIs' chances to be (well) ranked decrease as the competition becomes fiercer.

References to global rankings are made to stress the perceived problems of the domestic higher education system (low quality of research, low academic mobility, old-style governance) and to pinpoint the risks of delaying reform (a growing international 
marginalisation of the country, brain drain, and so on). The recipes for reform are then proposed: the introduction of 'healthy market mechanisms', the generalisation of fees to facilitate competition between public and private HEIs, and the concentration of funds in the best establishments (Jajszczyk, 2005). Skipping from academic to economic rankings based on different criteria reinforces the normalising power of rankings (Sauder and Espeland, 2009; Hazelkorn, 2011). It is also difficult to deconstruct the logic of the rankings' methodology in a public statement. Few people are interested in the criteria and weightings on which rankings are based. Attempts to demonstrate the inherent biases of rankings are often mocked as examples of provincialism.

\section{Rankings as an Ambiguous Instrument}

Although the principle of competition has dominated the narratives and justification of the reform design, it has elicited more diverse appreciations among the broader higher education policy community. Except for the few ranking entrepreneurs, the multiplication of global rankings and even the recent projects of the European Commission to develop alternative rankings (U-map, U-multirank) have not been met with widespread enthusiasm. Those who have been involved in the discussion on this topic agree that rankings are a double-edged instrument.

As far as rankings are concerned, I am not a fan, for one reason: they have such a heterogeneous methodology [...] this is why I am quite wary of rankings [...]. (Polish MP, 2011)

Experts who participate in European working groups devoted among others to the so-called 'transparency tools' emphasise the ambiguity of these instruments. They point out that although alternative ranking projects are not meant to rank HEIs, the practical application of these tools may very well lead to further classifications and evaluations. This might have 
tangible effects on the selection of partners for common projects, on the repartition of funds, on students' choices, and so on. These ambiguities add to the paradoxes of the Bologna Process, which are noticed even by its promoters: 'Did the Bologna Process activate tools of cooperation between domestic HEIs and higher education systems or did it instead activate tools of competition between them?' (Brdulak and Chmielecka, 2009)

This reaction seems common to several NMSs and neighbouring countries, whose representatives fear that these new tools, meant to enhance mobility and 'transparency', will eventually contribute to the brain drain and to a further marginalisation of the Central and East European academic space.

\section{For WhOM the RANKING TOLls? A ResOURCE FOR EXPERTS AND DECISION-MAKERS}

Research on higher education transformation has shown that ' $[r]$ eforms are driven both by the fear of falling behind and by promises of new resources.' (Olsen and Maassen, 2012, p. 8). In the case of EU NMSs, the European programmes and funds have been a considerable incentive to set up new curricula, reform strategies and agencies (Dakowska, 2011). The recent reforms have attempted to reorient the Polish higher education system around the principles of 'competitiveness', 'efficiency' and other economic rationales, such as the opening up of universities to employers. These reforms refer, directly or indirectly, to different development strategies advocated by the European Commission and to the provisions of the Lisbon strategy on higher education and research. This illustrates the global shift of EU educational policies towards a pro-market orientation (Walkenhorst, 2008), which has been characterised by an increasing stress on purposeful, productive education and applied research, along with the measurement of 'performance' (Keeling, 2006, p. 209).

\section{Diversification of HEI in Strategic Documents: A Consensual Aim}


The preparations of the recent legislative project on higher education exemplify the prevalence of market rationales. In 2009, the Ministry announced a call for projects for a strategy of higher education development. The winner was a project presented by the consulting firm Ernst \& Young and a liberal economic think tank, the Gdansk Institute for Market Economics (IBnGR). ${ }^{5}$ Both these structures brought together a team of experts mostly academic teachers - who had participated in the debate on higher education and called for a radical reform of the system. A conflict emerged as soon as the call for projects was published, as the Conference of Rectors of Academic Schools in Poland (KRASP), a major academic player, declared that the conditions of the call made it impossible to them to participate. Consequently, the Rectors' Conference mobilised its own resources to devise an alternative strategy.

The diagnosis made by the Ernst \& Young consortium refers to the recommendations of the European Commission, which calls, according to the authors, for a 'new model of higher education, based on leadership, management and entrepreneurship and not only on academic freedom and internal democracy' (Ernst \& Young Business Advisory and IBnGR, 2009, p. 17). Referring to reforms conducted in different European countries, they call for 'the reduction of the role of the state and an increased university autonomy; the diversification of HEIs; the concentration of research expenditure in the strongest universities; the professionalization of the management system', and so on (Ernst \& Young Business Advisory and IBnGR, 2009, p. 17). The report clearly takes a stance in favour of management methods inspired by the private sector. The rectors' team elaborated a more consensual proposal, which does not call for a radical governance reform. It refers to the Bologna Process, suggesting a stronger internationalisation of the system. This strategy also insists on the need to differentiate HEIs 'by using competition mechanisms'. The aim is to create institutions that 
would enjoy the status of a 'flagship university' or 'research university' and be able to ‘occupy higher positions in international rankings'. (KRASP, FRP and KRZaSP, 2009).

Paradoxically, the debate which followed these two competing proposals took place independently from the preparations of the Higher Education Act. The strategies could not be used as a working basis for the new legislation, as they were published at a stage when the legislative project was quite advanced. Finally, the government did not choose to venture on the politically dangerous field of the generalisation of fees, opting for more modest arrangements, such as paying for double majors. Ultimately, the new legislative Act includes the principle of a stronger differentiation among universities, the 'parametric' evaluation of HEIs and references to the requirements of the Bologna Process. The text allows university authorities to fire teachers more easily. It also introduces a number of mechanisms enabling closer ties with the economic environment. The recent reforms of Polish higher education have been designed to allow a stronger differentiation of Polish HEIs. However, this diversification has been under way for many years. The private sector that emerged after 1989 has mainly focused on teaching, especially at BA level. It remains largely dependent on fees. The state sector has suffered from chronic under-funding and research is supported largely by project grants attributed on the basis of competitive procedures.

\section{Referring to Competitiveness and Rankings as a Resource for the Positioning of Experts}

Several experts involved in the higher education development strategy commissioned by the ministry had taken clear stances in the debate on higher education. They have called for a farreaching reform inspired by the US model. However, most of them did not occupy central positions in higher education representative organs. Among the most active co-authors of the Ernst \& Young strategy, an economist and engineer, who had worked in the US during the 1980s before coming back to Poland to counsel the ministry of privatisations and manage 
several firms, exemplifies this liberal view. This person has occupied a rather marginal position in the academic field: he has worked for the Polish-American Chamber of Commerce while managing and counselling a private HEI. He gained his expert status owing among other things to a published monograph, in which he defends competition as the best way to reform Polish higher education and presents the US system as a model to follow (Thieme, 2009a).

In order to create HEIs of high quality, we need differentiation and competition. The main disease of public higher education is lack of competition. Only competition is able to boost initiative, to develop heterogeneity and to create conditions allowing the best to reach excellence [...]. There is no better mechanism to eliminate faculties and professors who teach poorly. (Thieme, 2009a, pp. 10-11)

Due to his open stance in favour of radical reform, this expert has been invited to participate in several ministerial working groups. Yet, neither him nor any of the other experts were consulted on the final text of the higher education reform act. Taking an active part in the public debate and referring to rankings provided him with some visibility but did not modify his institutional position.

Among the most visible members of the Ernst \& Young team (known from his numerous public statements in the press), another engineer and full professor teaching at a technical HEI has managed to combine more decisive resources. Born in 1952, this expert has also accumulated international experience, having lived and taught in several Western countries. His background is a more academic one: he has won several prestigious academic distinctions in Poland and participates in various international scientific journals and associations. Designated as the candidate of the governing party, the liberal Civic Platform, during the Parliamentary elections of 2005 , he also had political capital. These combined 
resources were instrumental in his nomination, in March 2011, as director of the National Science Centre, a newly created governmental agency designed to manage and distribute public funds for fundamental research. In this case, the lacking academic institutional capital (Bourdieu, 1984) was compensated by his intellectual and symbolic resources, prestige and political capital. ${ }^{6}$

The international networking reinforced by the global rankings has benefited to people who have accumulated either international expertise or domestic experience with HEI league tables. Classifying HEIs in a rapidly expanding educational market has become a daily business for some. Thus, the Perspektywy publishing house and educational foundation, both founded by a Polish journalist specialised in information technology, have published the first educational rankings in Poland, focused initially on secondary education, since 1992 (Siwiński, 2002). In 2000, they started to publish league tables of public and private HEIs, who gained a wide public audience owing to a partnership with a leading newspaper, Rzeczpospolita. The company managed both to convince HEIs to participate in the project and to gain an international recognition thanks to the steady efforts made by the team to ensure a professional methodology and several legitimising devices such as the development of a Ranking Board. However, the growing importance of international rankings is probably the most important factor which has given new clout to domestic ranking enterprises. Acknowledging the importance of higher education internationalisation, KRASP set up a strategic partnership with the Perspektywy Foundation to manage the promotional campaign 'Study in Poland'. Owing to this partnership, Perspektywy Foundation could become a member of the Academic Cooperation Association, which brings together mainly public organisations active in the field of higher education international promotion and academic exchange. Benefiting from the international networking linked to the ranking business, the Perspektywy president contributed to the creation of the International Observatory on 
Academic Ranking and Excellence in Berlin, of which he was elected vice-chairman in $2009 .^{7}$ This case illustrates how the thriving global market strengthens the domestic business of the supply of ranking (and of the supposed demand).

The Polish Minister of Science and Higher Education clearly follows this logic, which makes excellence dependent on competition. Commenting the legal acts on higher education, she stated that she wanted to 'introduce a maximum of open competition mechanisms, also as far as fundraising is concerned' (Kudrycka, 2010). When presenting the new reform to journalists, she declared that the aim was to lead five Polish universities to the first hundred positions of the Shanghai ranking within five years (Ministry of Science and Higher Education, 2010). The authors of the reform structured the text around the creeds of 'autonomy', 'opening up to the world' and 'entrepreneurship'. In 2012, extra funds have been earmarked to reward the country's 25 'best faculties (selected upon parametric evaluation and quantitative indicators of 'scientific effectiveness'). The announcement of the Leading National Research Centres - an excellence initiative of sorts, which should receive up to 50 million zloty (about 12.5 million euros) for each of them within five years took place in June 2012. The vocabulary of competition dominates the announcements of these measures.

Polish HEIs can become the best universities in Europe. By saying this I am not denying reality and the middling position of our HEIs in international rankings. As a matter of fact, today, elite units are emerging, which can fight for the position of European leaders. (Kudrycka, 2012)

This case confirms the observation made by Hazelkorn (2011), according to whom 'Rankings amplify the growing gap between elite and mass education, heightening the value of key "positional goods" essential for global competitiveness, and intensifying the attractiveness of winners with consequential implications for social equity and other institutions and countries' (p. 28). 
However, it must be acknowledged that, on the political level, the successive higher education reforms have not sparked major controversies in Poland. During parliamentary debates, politicians on the left did not oppose the principle of competition between HEIs, even if their discourse was tinged with more social accents. This reluctance to criticise the notion of competition and of market rules applied to HEIs should be understood in a more general context of post-communist transition and EU accession. Compared to the communist period, associated with a centrally planned economy and shortages, the concepts of free initiative, market forces and competition are often linked with positive values (Dakowska and Hubé, 2011). Opposing the idea of the free market is perceived as illegitimate and may be risky for left-wing politicians because of their supposed connection with the former communist party.

If we look at rankings as global 'policy scripts' (Hazelkorn, 2011; Schofer and Meyer, 2005; Kauppi and Erkkilä, 2011), the Polish reform design reproduces trends observed in other regions of the world: concentration of resources, stronger evaluation of higher education and research institutions and of the academics themselves, the creation of poles of excellence, an attempt to steer research politically by providing funding to strategic branches. However, a distinction must be made between the reform announcement and the reform outcome as such. Although it is too early to evaluate the implementation of the reform, it is uncertain whether the announced reorientation of public funds will have any impact on the emergence of 'excellence centres', let alone ones with high international rankings. As the position of HEIs in global rankings is correlated with their budget, the ones that fare the best are universities with considerable private funds, which leaves little chance for most CEEC HEIs to join this exclusive club.

\section{CONCLUSION}


The Polish case confirms the observation that rankings are a driving force of the 'geo-political battle for excellence' (Hazelkorn 2011, p. 81) as they favour reform activism. However, it is not easy to trace a link between calls for reform and the final legislative outcome. On the one hand, focusing on the way the reform is presented and justified, it is possible to notice parallels between both narratives. On the other hand, it would be exaggerated to argue that the reference to rankings had a clear and direct impact on the reform itself. Even if competition and evaluation have been established as key principles and should lead to the elimination of the weakest research centres, it is far from certain that the new policy will result in a new stratification of HEIs and in the emergence of internationally leading establishments. Moreover, the funds committed are modest in light of the reform's ambition. Also, the calls for a far-reaching reform have been toned down by the mobilisation of the academic community with its established representatives, which led to the safeguarding of the core of the system, that is, the existing HEI governance.

In many respects, the Polish case is just a declination of more general trends of university modernisation. The narrative of an accumulated performance crisis and the subsequent demands of radical reform are the bread and butter of most European higher education policies. The necessity to compete in a global knowledge market and to develop high-level skills is put forward together with the fact that Europe's universities 'are lagging behind the best universities in the USA and because upcoming China and India will make competition among universities even stiffer' (Olsen and Maassen 2010, p. 3).

Rankings and their impact must be studied within a broader context of higher education internationalisation. Rankings are a mere façade - if not a broken mirror - of national academic systems with their historically established HEIs. When experts and decision-makers seek inspiration in rankings, they refer to different academic institutions, traditions and policies which are considered as models but hard to imitate. Due to their appearance of 
objectivity, rankings encourage these attempts at emulation. In the case of CEECs, this outward look bears not only a threat (of revealing a systemic lag and further weakening their position in international competition for students) but also an opportunity (to develop a domestic ranking business, showcase their HEIs' achievements, communicate about their own educational offer, participate in international discussions on equal footing and, last but not least, get access to extra funding).

Regarding the matter of impact, although it is still too early yet to assess the results of the implementation of the recent legislative acts, the paradoxes that lie behind the argument of diversity are worth remarking upon (Nixon, in this volume; Kehm, in this volume). According to Jon Nixon, the marketization of higher education - based on the idea of competition - has resulted in a trend of conformism, as HEIs strive to resemble the ideal type of 'market leaders'. Single league tables tend to favour one exclusive model: that of a 'comprehensive research-intensive university' (Marginson and van der Wende, 2007, p. 308). Attempting to join this top league seems like a Sisyphean endeavour, as the first places are reserved to the most eminent and rich English-speaking, mainly American universities (cf. Kehm, in this volume; Hazelkorn 2011). The consequence is a growing inequality of the university funding (Nixon, this volume). While it is difficult to make any predictions about the evolution of the Polish university system, the current system is quite likely to further reproduce the persistent structural gaps.

\section{Notes}

1. The author would like to thank Tero Erkkilä and Jay Rowell for their comments on the previous drafts of this contribution.

2. Before the creation of the $\mathrm{KBN}$, the principle of competition for grants had been established, also based on the US example. The American Embassy financed several 
study trips of Polish researchers and governmental advisors. These exchanges have inspired, among others, the creation of accreditation bodies.

3. Several provisions facilitate the creation and running of private HEIs. Moreover, without limiting itself to the distinction between public and non-public establishments, the Act paves the way for the development of fee-charging courses by introducing the distinction between full-time day studies, evening studies and extramural studies.

4. The legal package of Six Acts reforming Polish Science has been adopted by the Parliament almost unanimously, published on 4 June 2010 and entered into force on 1 October 2010. One of its main aims was to create conditions for more private sector involvement in the funding of research. Interview with a high-ranking civil servant in the Ministry of Science and Higher Education, Warsaw, 22 October 2011.

5. Founded in 1989 by liberal economists close to the first democratic governments, this institute has provided scientific justification and expertise to the process of privatisations of state property. It is the home institution of the present Commissioner for financial programming and budget, Janusz Lewandowski.

6. Concerning the combination of these different resources by researches of several generations on the case of Czech Europeanists, see Neumayer (2010).

7. The President is Jan Sadlak, an international higher education expert. He was Chief of Section for Higher Education Policy at UNESCO, Paris (1992-99), director of UNESCO-European Centre for Higher Education in Bucharest (1999-2009), vicepresident of a private HEI in Warsaw (2009-2011) and professor at the Faculty of European Studies of the Babeș-Bolyai University in Cluj-Napoca, Romania.

\section{References}

Bourdieu, P. (1984) Homo academicus (Paris: Les éditions de minuit). 
Brdulak, J. and E. Chmielecka (2009) 'Nowe klasyfikacje' (New Classifications), Forum Akademickie, No. 11.

Civil servant, Ministry of Science and Higher Education, Warsaw, interview on 20 July 2010.

Dakowska, D. and N. Hubé (2011) 'For or Against the EU? Ambivalent Attitudes and Varied Arguments towards Europe', in D. Gaxie, N. Hubé and J. Rowell (eds) Perceptions of Europe: A Comparative Sociology of European Attitudes (Essex: ECPR Press).

Dakowska, D. (2011) 'Translating European Higher Education Policies in the Light of Liberal Transformations: The Case of Polish Educational Entrepreneurs', Paper presented at the 6th ECPR General Conference, Reykjavik, 25-27 August 2011, Section 51: Europe of Knowledge (Education, Higher Education and Research Policy), Panel 499 'The Europe of Knowledge and its Ignored Labourers: Translating European Education policies'.

Dakowska, D. (forthcoming) 'Higher Education Reform in Poland: Between Privatisation and Europeanisation', European Journal of Education.

Dobbins, M. and C. Knill (2009) 'Higher Education Policies in Central and Eastern Europe: Convergence towards a Common Model?', Governance: An International Journal of Policy, Administration and Institutions, 22 (3), 397-430.

Dobbins, M. (2011) Higher Education Policies in Central and Eastern Europe: Convergence towards a Common Model? (Houndmills, Basingstoke, Hampshire: Palgrave Macmillan).

Ernst \& Young Business Advisory and IBnGR (2009) Diagnoza stanu szkolnictwa wyższego w Polsce, Report published in November 2009, http://www.nauka.gov.pl/fileadmin/user_upload/Finansowanie/fundusze_europejskie/P O_KL/Projekty_systemowe/20100727_SSW2020_strategia.pdf, date accessed 23 December 2012.

Erkkilä, T. (2013), 'Introduction: University Rankings and Europe’, in this volume. 
Erkkilä, T. and O. Piironen (2013) 'Global University Rankings, Politics and Reflexivity of Institutional Autonomy and Accountability', in this volume.

Gornitzka, Å. and P. Maassen (2011) 'University Governance Reforms, Global Scripts and the "Nordic Model": Accounting for Policy Change?" in J. Schmid, K. Amos, J. Schrader and A. Thiel (eds) Welten der Bildung? Vergleichende Analysen von Bildungspolitik und Bildungssystemen (Baden-Baden: Nomos Verlagsgesellschaft), 149-77.

Hazelkorn, E. (2011) Rankings and the Reshaping of Higher Education: The Battle for World-Class Excellence (Houndmills, Basingstoke, Hampshire: Palgrave Macmillan).

Jabłecka, J. (2009) 'Revolution and Evolution in the Organization of Public Research Funding in Poland between 1991 and 2007', in J. Jabłecka, Public Research Funding: Research Councils, Funding Instruments, Evolution of the System in Poland (Warsaw: Centre for Science Policy and Higher Education, University of Warsaw).

Jackowski, S. (2004) 'Uczelnie na zakręcie' (HEIs at the Crossroads), Forum akademickie, No. 3 .

Jajszczyk, A. (2005) 'Skazani na bylejakość?' (Doomed to Remain Average?), Gazeta wyborcza, 30 March 2005.

Jajszczyk, A. (2008) 'Polskie uniwersytety potrzebują reanimacji' (Polish Universities Need Reanimation), Rzeczpospolita, 26 February 2008.

Jajszczyk A. (2009) 'Smutna prawda rankingów' (The Sad Truth of Rankings), Dziennik Polski, No. 271, 19 November 2009.

Kauppi, N. and T. Erkkilä (2011) 'The Struggle Over Global Higher Education: Actors, Institutions, and Practices', International Political Sociology, 5(3), 314-26.

Keeling, R. (2006) 'The Bologna Process and the Lisbon Research Agenda: The European Commission's Expanding Role in Higher Education Discourse', European Journal of Education, 41(2), 203-22. 
Kehm, B. M. and B. Stensaker (2009) University Rankings, Diversity, and the New Landscape of Higher Education (Rotterdam: Sense Publishers).

Kehm B. M. (2013), 'The Impact of Rankings on the European Higher Education Landscape', in this volume.

KRASP, FRP and KRZaSP (2009) Polskie Szkolnictwo Wyższe: Stan, uwarunkowania, perspektywy, http://www.krasp.org.pl/pl/strategia/strategia, date accessed 26 December 2012.

Kudrycka, B. (2010) 'Uczelnie potrzebują konkurencji' (HEIs Need Competition), interviewed by M. Suchodolska and K. Klinger, Dziennik Gazeta Prawna, 25 May 2010, p. 6 .

Kudrycka, B. (2012) 'Najlepsi podejmują konkurencję ze światem' (The Best Compete with the World), Polish Ministry of Science and Higher Education, 6 June 2012, http://www.nauka.gov.pl/ministerstwo/zdaniem-ministra/zdaniemministra/artykul/najlepsi-podejma-konkurencje-ze-swiatem/, date accessed 26 December 2012.

Marginson, S. and M. van der Wende (2007) 'To Rank or To Be Ranked: The Impact of Global Rankings in Higher Education', Journal of Studies in International Education, 11(3-4), 306-29.

Ministry of Science and Higher Education (2010), Reforma Nauki I Szkolnictwa Wyzszego (power point presentation to the press).

Neumayer, L. (2010) 'Les études européennes en République tchèque: Entre héritages communistes et incitations communautaires', Politix, 2010/1, No. 89, 125-44.

Nixon, Jon (2013), 'The Drift to Conformity: The Myth of Institutional Diversity', in this volume. 
Olsen, J. P. and P. Maassen (2010) 'European Debates on the Knowledge Institution: The Modernization of the University at the European Level', in P. Maassen and J. P. Olsen (eds) University Dynamics and European Integration (Dodrecht: Springer).

Pirker T., M. R. Lepsius, R. Weinert, H.-H. Hertle (1995) Der Plan als Befehl und Fiktion: Wirtschaftsführung in der DDR - Gespräche und Analysen (Opladen: Westdeutscher Verlag).

Polish MP, Warsaw, Interview on 27 April 2011.

Rowell, J. (2006) Le totalitarisme au concret: Les politiques du logement en RDA (Paris: Economica).

Rowell, J. and M. Mangenot (eds) (2011) A Political Sociology of the European Union: Reassessing Constructivism (Manchester: Manchester University Press).

Sauder, M. and W. N. Espeland (2009) 'The Discipline of Rankings: Tight Coupling and Organizational Change', American Sociological Review, 74(1), 63-82.

Shin, J. C.; Toutkoushian, R. K.; Teichler, U. (Eds.) (2011) University Rankings. Theoretical Basis, Methodology and Impacts on Global Higher Education (Dodrecht: Springer).

Schofer, E. and J. W. Meyer (2005) 'The Worldwide Expansion of Higher Education in the Twentieth Century', American Sociological Review, 70(6), 898-920.

Siwiński, W. (2002) 'Perspektywy - Ten Years of Rankings', Higher Education in Europe, 27(4), 399-406.

Thieme, J. K. (2009a) Szkolnictwo wyższe. Wyzwania XXI wieku. Polska, Europa, USA (Higher Education. Challenges of the 21st Century. Poland, Europe, USA) (Warsaw: Engram/Difin).

Thieme, J. K. (2009b) 'Zróbmy sobie Oksford' (Let's Create Oxford), Gazeta wyborcza, 26 October 2009.

Tofallis, C. (2012) 'A Different Approach to University Rankings', Higher Education, 63(1), $1-18$. 
Tomusk, V. (ed.) (2007) Creating the European Area of Higher Education: Voices from the Periphery (Dodrecht: Springer).

Usher, A. and J. Medow (2009) 'A Global Survey of University Rankings and League Tables', in B. M. Kehm and B. Stensaker (eds) University Rankings, Diversity, and the New Landscape of Higher Education (Rotterdam: Sense Publishers).

Walkenhorst, H. (2008) 'Explaining Change in EU Education Policy', Journal of European Public Policy, 15(4), 567-87. 